Portland State University

PDXScholar

\title{
Localization of neurosecretory cells within the cerebral ganglia of Amphiphorus imparispinosus Griffin, 1898 (Hoplonemertea) and their possible regulatory role in the annual reproductive cycle
}

Gail H. Jacobson

Portland State University

Follow this and additional works at: https://pdxscholar.library.pdx.edu/open_access_etds

Part of the Biology Commons, and the Cell Biology Commons Let us know how access to this document benefits you.

\section{Recommended Citation}

Jacobson, Gail H., "Localization of neurosecretory cells within the cerebral ganglia of Amphiphorus imparispinosus Griffin, 1898 (Hoplonemertea) and their possible regulatory role in the annual reproductive cycle" (1977). Dissertations and Theses. Paper 2517.

https://doi.org/10.15760/etd.2514

This Thesis is brought to you for free and open access. It has been accepted for inclusion in Dissertations and Theses by an authorized administrator of PDXScholar. Please contact us if we can make this document more accessible: pdxscholar@pdx.edu. 
AN ABSTRACT OF THE THESIS OF Gail H. Jacobson for the Master of Science in Biology presented 12 August 1976.

Title: Localization of Neurosecretory Cells within the Cerebral Ganglia of Amphiphorus imparispinosus Griffin, 1898 (Hoplonemertea) and Their Possible Regulatory Role in the Annual Reproductive Cycle APPROVED BY MEMBERS OF THE THESIS COMMITTEE:
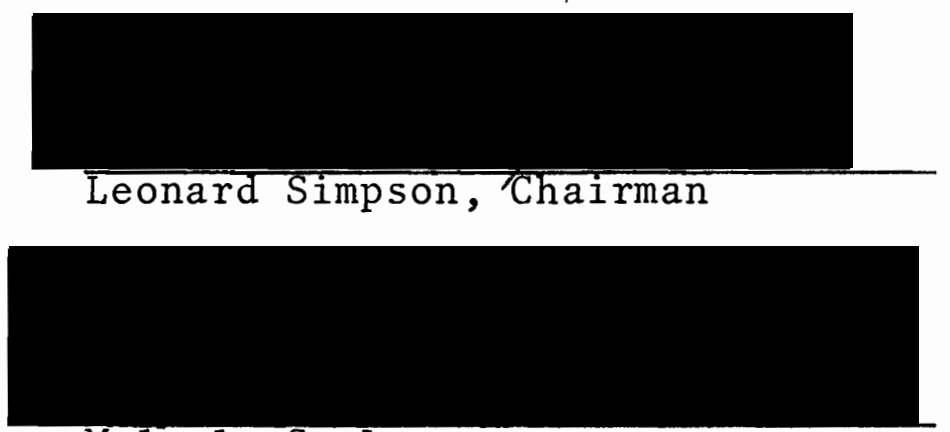

Malcolm S. Lea

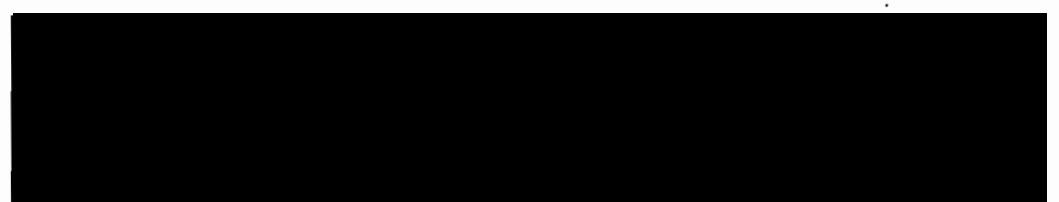

Earl Fisher, Jr.

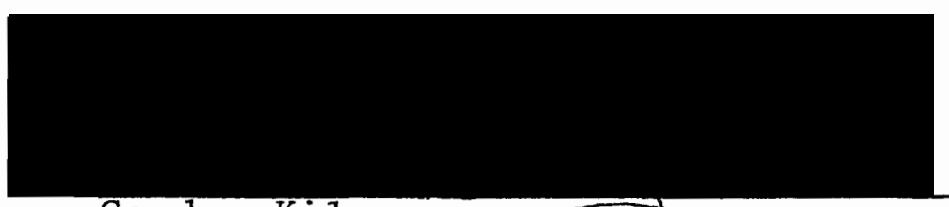

Gordon Kilgour

Nemerteans are common invertebrates along coastlines in both temperate and arctic climates throughout the world. Amphiphorus imparispinosus is a carnivorous member of this 
phylum that is found abundantly in the intertidal areas of the Oregon coast. As in many other invertebrate phyla, endocrine integration within the nemerteans is thought to be accomplished by neurosecretory mechanisms. In Amphiphorus the presence of these neurosecretory systems has not been previously shown. This project was undertaken to determine if neurosecretory cells are present within the central nervous system of this species and further, to examine seasonal changes in the number and appearance of these cells. The second objective of this research was to determine the reproductive cycle of Amphiphorus and to examine a possible correlation between this cycle and seasonal changes in the neurosecretory system.

Animals were collected from the northern Oregon coastline on a monthly basis for one year. The anterior portion of each specimen was fixed in Helly's fluid and stained with paraldehyde fuchsin to reveal neurosecretory cells within the cerebral ganglia. The sexual state of each animal was determined by examining the development stage of gametes from a mid-body section.

Changes in the number of neurosecretory cells found within the cerebral ganglia of animals collected over the year suggests an annual cycle of activity. The number of neurosecretory cells is lowest during January and February. This number increases steadily during the spring and summer months reaching its highest level in August and September, 
then dropping sharply again in October. Examination of gametes from each specimen revealed that the sex cells develop slowly during the summer and fall months. From October to February the gametes undergo a dramatic increase in size. Spawning occurs during February and March: the months when the number of neurosecretory cells is lowest. The inverse relationship between the apparent neurosecretory cycle and the reproductive cycle in Amphiphorus suggests that the substance elaborated by the neurosecretory cells may have an inhibitory effect on the development of gametes in this species. The results of this study are in accord with experimental data indicating the presence of an inhibitory factor influencing reproduction in other nemertean species. 
LOCALIZATION OF NEUROSECRETORY CELLS WITHIN THE CEREBRAL GANGLIA OF Amphiphorus imparispinosus GRIFFIN，1898 (HOPLONEMERTEA) AND THEIR POSSIBLE REGULATORY ROLE IN THE ANNUAL REPRODUCTIVE CYCLE by GAIL H. JACOBSON

A thesis submitted in partial fulfillment of the requirements for the degree of

\author{
MASTER OF SCIENCE \\ in \\ BIOLOGY
}




\section{TO THE OFFICE OF GRADUATE STUDIES AND RESEARCH:}

The members of the Committee approve the thesis of Gail H. Jacobson presented 12 August 1976.

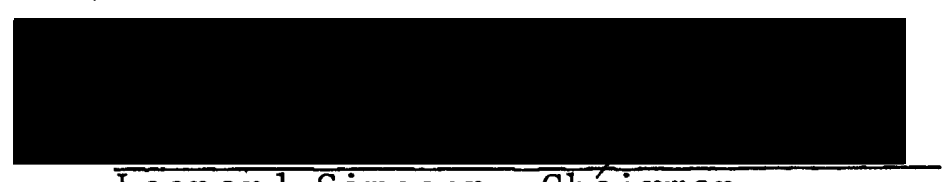

Leonard Simpson, Chairman

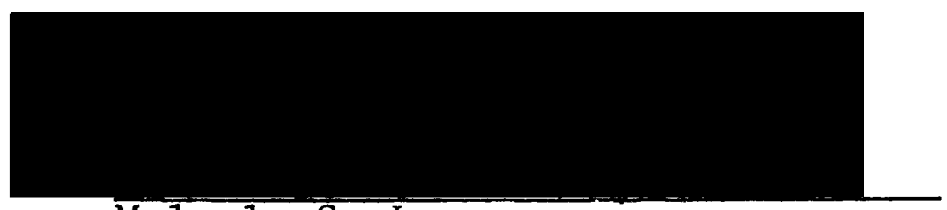

Malcolm S. Lea

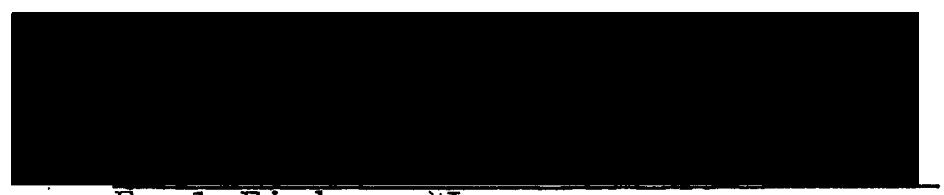

Earl Fisher, "Jr.

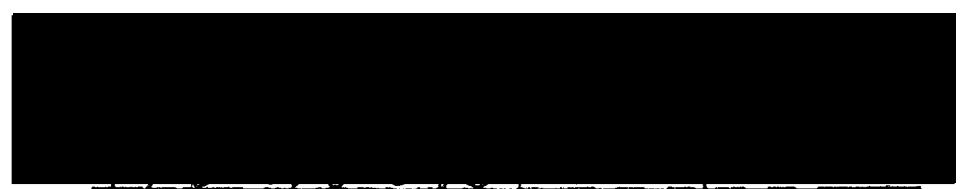

Ģrdon Kilgour

APPROVED :

W. Herman Taylor, Head, Debartment of Biology

Stanfey E. Rauch, Dean of Graduate Studies and Research 


\section{ACKNOWLEDGEMENTS}

It is my pleasure to thank several persons who gave very valuable assistance in the research and writing of this paper. My advisor, Dr. Leonard Simpson, gave freely of his time and knowledge on innumerable instances. Dr. Malcolm Lea translated all of the French literature cited in the text. Mr. Birck Cox is responsible for the excellent three-dimensional drawing of the internal anatomy of Amphiphorus. My husband, Andy Jacobson, deserves many thanks for his financial and emotional support throughout. 
TABLE OF CONTENTS

PAGE

ACKNOWLEDGEMENTS ....................... ii

LIST OF TABLES....................... v

LIST OF FIGURES $\ldots \ldots \ldots \ldots \ldots \ldots \ldots \ldots \ldots \ldots \ldots \ldots \ldots \ldots \ldots$

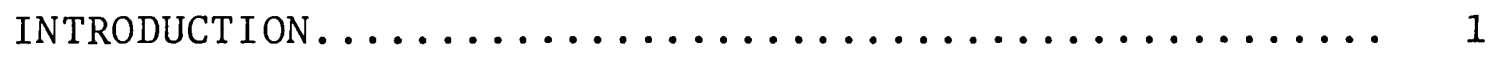

MATERIALS AND METHODS................... 8

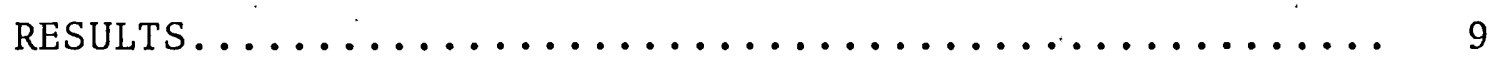

I. Histology of the Neurosecretory System..... 9

II. Cyclical Neurosecretory Activity......... 14

III. The Reproductive Cycle............... 14

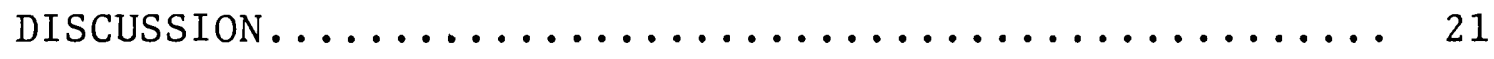

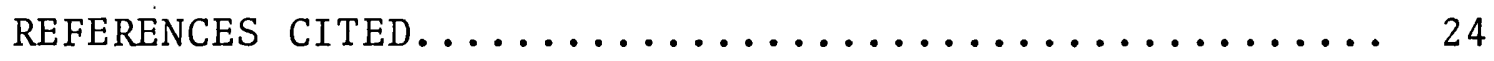




\section{LIST OF TABLES}

\section{TABLE}

I Average Number of Total Neurosecretory

Ce11s and Average Number of $A$ and $B$

Cells Found in the Cerebral Ganglia of

Amphiphorus from April 1973 to February

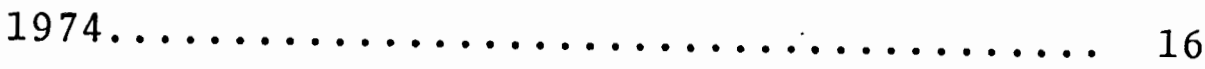




\section{LIST OF FIGURES}

FIGURE

PAGE

1 A - Anterior portion of Amphiphorus imparispinosus illustrating major organ systems. B - Cross section through the cerebral ganglia. C - Cross section posterior to cerebral ganglia.................. 10

2 Cross-section of the right dorsal cerebral ganglion of Amphiphorus imparispinosus showing an A cell (A)................ 11

3 a - Cross section through the left dorsal cerebral ganglion of Amphiphorus imparispinosus showing several $B$ cells (B). b - Cross section through left ventral cerebral ganglia with 1arge $B$ cel1.................... 12

4 Cross section through right dorsal cerebral ganglion of Amphiphorus imparispinosus showing the accumulation of neurosecretory products (NS) near a blood vessel (V) indicating a possible neurohaemal area............. 13 
5 Annual cycle of mean total numbers of neurosecretory cells in the cerebral ganglia of Amphiphorus imparispinosus collected April

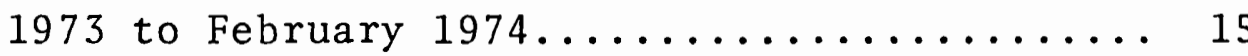

6 Annual cycle of mean numbers of stainable A-ce11s and B-cells, and of mean total number of neurosecretory cells in the cerebral ganglia of Amphiphorus imparispinosus collected April 1973

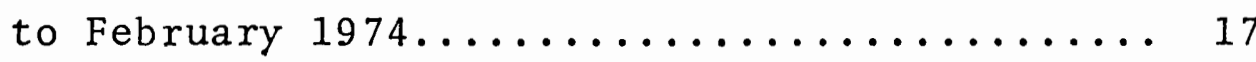

7 Cross section of a gravid female collected in February showing mature ova(0). X125....... 19 8 Annual neurosecretory and reproductive cycles in Amphiphorus imparispinosus............. 20 


\section{INTRODUCTION}

The phylum Nemertea constitutes a group of animals which are the most complex of the acoelomate bilateria. They are elongate, bilaterally symmetrical and somewhat flattened with body construction essentially similar to the Platyhelminthes but showing several advances over the flatworms (Bayer and Owre, 1969). Most species are marine but there are fresh water and land forms. Marine species are abundant along coastlines in temperate as well as arctic regions where they are carnivors feeding primarily on annelids and other small invertebrates (Wilmoth, 1967). Considering their numbers, nemerteans undoubtedly occupy an important niche in the intertidal ecosystem.

Fundamental body structure within the phylum includes a ciliated epidermis with associated gland and sensory cells. Beneath the epidermis a layer of connective tissue constitutes the dermis. Lying beneath the dermis, the body wall musculature is composed of two or three layers of circular and longitudinal muscle tissue the number and arrangement of which depend upon the species. Mesenchyme fills the spaces between the body wall and the organ systems.

Nemerteans have a complete digestive system with anterior mouth opening and posterior anal opening. This represents a significant evolutionary advancement over the 
flatworms from which the phylum is thought to be derived. Just dorsal to the gut lies the proboscis apparatus, a prey capturing organ which is peculiar to the nemerteans. A1though the proboscis is a feeding structure it is not part of the digestive system. It is contained within a separate body cavity, the rhynchocoel, which results embryologically from an invagination of the epidermis. The proboscis sheath lines the fluid-filled rhynchocoel and is continuous anteriorly with the proboscis itself. Extrusion of the organ is caused by hydraulic pressure produced when the circular muscle of the sheath compresses the fluid within the rhynchocoel. Upon contraction the proboscis is rapidly shot through the anterior proboscis pore, much as a sleeve is turned inside out (Hyman, 1951). In the Order Hoplonemertea the proboscis is armed with a stylet which is used to pierce and hold the prey. Toxic secretions from accessory glands associated with the stylet apparently immobilize the victim. The proboscis is then wound around the prey and serves to pull the animal toward its captor. This is accomplished by means of a retractor muscle which attaches the proboscis to the proboscis sheath posteriorly (MacGinitie and MacGinitie, 1949). In Amphiphorus as in other members of the order, the digestive tract has a common opening with the rhynchocoel such that a separate mouth opening is not present.

With the nemerteans a closed circulatory system appears for the first time within the Metazoa. The simplest 
arrangement consists of two lateral blood vessels connected anteriorly and posteriorly by blood lacunae. No pumping organs are present and circulation is accomplished by contraction of the large vessels. Closely associated with the circulatory system are the protonephridia which serve as excretory organs for the phylum.

The nervous system consists of a simple nerve plexus, paired lateral nerve cords and the cerebral ganglia (brain). The cerebral ganglia are composed of two dorsal ganglia connected by lateral commissures to two ventral ganglia. Associated with the brain and anterior to it are paired structures called cerebral organs. Composed of both glandular and nervous tissue they are connected posteriorly to the dorsal ganglia by thick nerve tracts and at the same time are in contact with the external environment via ciliated canals opening on the dorsal surface (Barnes, 1974). The cerebra1 organs appear to have a chemoreceptive role in the process of food detection (Ling, 1969) as well as a possible endocrine function. E. Ling (1970) suggests the cerebral organs may be responsible for osmotic regulation.

In the nemerteans, as well as in other lower Metazoa, the absence of any proven epithelial endocrine organs predicates the belief that endocrine integration must be accomplished primarily through neurosecretion (Highnam and Hil1, 1969). Neurosecretory cells are dually specialized structures located within the nervous system and having 
properties typical of nerve cells, but also capable of secreting hormones (Bern and Knowles, 1966; Clark, 1966; Gersch, 1969). Morphologically, neurosecretory cells are similar to neurons in as much as they have axons. Nissl granules, dendrites and neurofibrillae. They are also capable of transmitting nervous impulses but differ from ordinary neurons in several important aspects: they do not innervate effector organs nor do they make synaptic connections with other neurons. Unique also to the neurosecretory neurons is the ability to secrete biologically active materials which may have their effect at some distance away from the release site (Highnam and Hil1, 1969). This association of glandular and neuronal properties appears to give the neurosecretory cell its special function: the release of hormonal material in response to nervous stimuli (Bern, 1963).

The hormones synthesized by neurosecretory cells can often be made visible for light microscopy by means of standard staining techniques utilizing chromehematoxylin or paraldehyde fuchsin (Gabe, 1966, 1968). These stains, however, are not specific for neurosecretory material and the presence of stainable cells within the nervous system only indicates the possible presence of neurosecretory function (Bern and Hagadorn, 1965).

In electron micrographs, neurosecretory cells are found to contain electron dense, membrane bound granules 
ranging from $1,000-3,000 \AA(100-300 \mathrm{~nm})$ in diameter.

These structures appear to originate in the Golgi apparatus in a manner similar to protein droplet formation in other gland cells (Knowles, 1962). As with stains for light microscopy, the finding of this type of granule cannot be accepted as definitive proof of neurosecretory function. Cytological evidence should be substantiated by experimental data.

In the invertebrates, the worms as a group have been demonstrated to rely upon neurosecretory mechanisms within the central nervous system as a source of hormones (Scharrer, 1955). Cytological studies have shown evidence of neurosecretory cells within the central nervous systems of members of the Platyhelminthes, Nematoda and Annelida (for reviews see Bern and Hagadorn, 1965; Durchon, 1967). Endocrine control of reproductive physiology in the annelids has been experimentally shown in both polychaetes and oligochaetes. The cerebral ganglion or the associated infracerebral organ has proven to be the source of a reproductive hormone in the nereid polychaetes. It apparently has a dual effect. The hormone inhibits premature sexual development in both male and female juveniles. Decerebration results in the precocious appearance of mature sex cells while reimplantation or injection of brain extracts prevents this phenomenon. At a later stage of development a tropic influence by the cerebral ganglia on maturation of sex cells 
has also been observed. The nature of the effect of decerebration seems to depend on the developmental stage of the animal. In the polychaete, Arenicola, and the oligochaete, Eisenia, the cerebral control over gamete development appears to be one of stimulation (reviews by Clark, 1969; Golding, 1972).

H. Lechenault (1962) was the first to report the presence of possible neurosecretory cells within cerebral ganglia of nemerteans. In several species of Lineus (Heteronemertea); cells which stained with paraldehyde fuchsin and chrome hematoxylin were found scattered within the cerebral ganglion. Stainable material was seen to travel down the cell axon in some cases. Certain nerve cells within the cerebral organ also appeared to be secretory in nature. Further cytological studies within the Heteronemertea gave similar results (Bianchi, 1969;

Servettaz and Gontcharoff, 1973, 1974). Neurosecretory cells have also been demonstrated in four species within the Order Hoplonemertea (Lechenault, 1963).

J. Bierne $(1964,1966)$ first demonstrated experimentally a neurosecretory control over sexual maturation in Lineus ruber. Removal of the cerebral ganglia of females during the quiescent stage of the annual reproductive cycle brought about premature development of both somatic and germinal sex characteristics. Later experiments on Lineus ruber (Bierne, 1973) demonstrated that 
removal of the cerebral ganglia of immature females led to precocious sexual maturation while reimplantation of the ganglia prevented this phenomenon. Bierne thus postulated the presence of an inhibiting factor ("le facteur hormonal gonado-inhibiteur") produced by neurosecretory cells within the cerebral ganglia of prepuberal females.

This study was undertaken to demonstrate the presence of possible neurosecretory cells within the central nervous system of Amphiphorus imparispinosus (Hoplonemertea) and to correlate changes within these cells with the annual reproductive cycle. 


\section{MATERIALS AND METHODS}

Animals were collected from the northern Oregon coastline on a monthly basis from August 1973 to August 1974 as weather and tide would permit. The collecting area was bounded by Cape Lookout on the north, southward to Seal Rock State Park. Specimens were maintained in the lab in small fingerbowls of seawater at $54^{\circ}$ Fahrenheit.

The absence of data on the annual reproductive cycle of Amphiphorus imparispinosus made it necessary to first determine the time of year at which gamete release occurs. To accomplish this and at the same time determine the presence of neurosecretory products within the central nervous system, the worms were anesthetized in isotonic ( $0.9 \%)$ magnesium chloride and the anterior head region as well as a section taken from the mid-body region were removed from each animal. The head and mid sections were then fixed in Helly's fluid: saturated aqueous mercuric chloride, 100 cc; potassium bichromate, $2.5 \mathrm{gm}$; formalin, $7.5 \mathrm{cc}$. Fixation was accomplished over a period of 12 hours followed by post fixing with $4 \%$ formalin for an additional 12 hours. The tissues were then dehydrated to $70 \%$ ethanol and held in this solution until they were embedded in paraffin. Serial sections were stained with paraldehyde fuchsin (Gabe, 1968) followed by Clark's counter-stain (Clark, 1955). 


\section{RESULTS}

\section{HISTOLOGY OF THE NEUROSECRETORY SYSTEM}

The structure of the central nervous system of Amphiphorus imparispinosus and its relationship to other major organ systems is illustrated in Figure 1. The brain consists of paired, fused dorsal and ventral ganglia connected by thick commissures that form a ring around the esophagus. Lateral nerve cords emerge from the ventral ganglia and extend the length of the animal. Two types of neurosecretory cells were found scattered throughout the dorsal and ventral ganglia. These are designated as types $A$ and $B$ according to the criteria established by Lechenault (1963), Bianchi (1969) and Servattaz and Gontcharoff (1974) for the classification of nemertean neurosecretory cells.

A cells are small ( 3 to $5 \mu$ ), pyriform and stain intensely with paraldehyde fuchsin. The nucleus is large (Fig. 2). Type B cells are much larger (15 to $20 \mu)$ and more rounded. The cytoplasm of $B$ cells is voluminous and stains with variable intensity with paraldehyde fuchsin. The nucleus is prominent (Fig. 3). Evidence of axonal transport of neurosecretory material into the axon bundle can sometimes be seen but a specific release site cannot be positively identified (Fig. 4). 


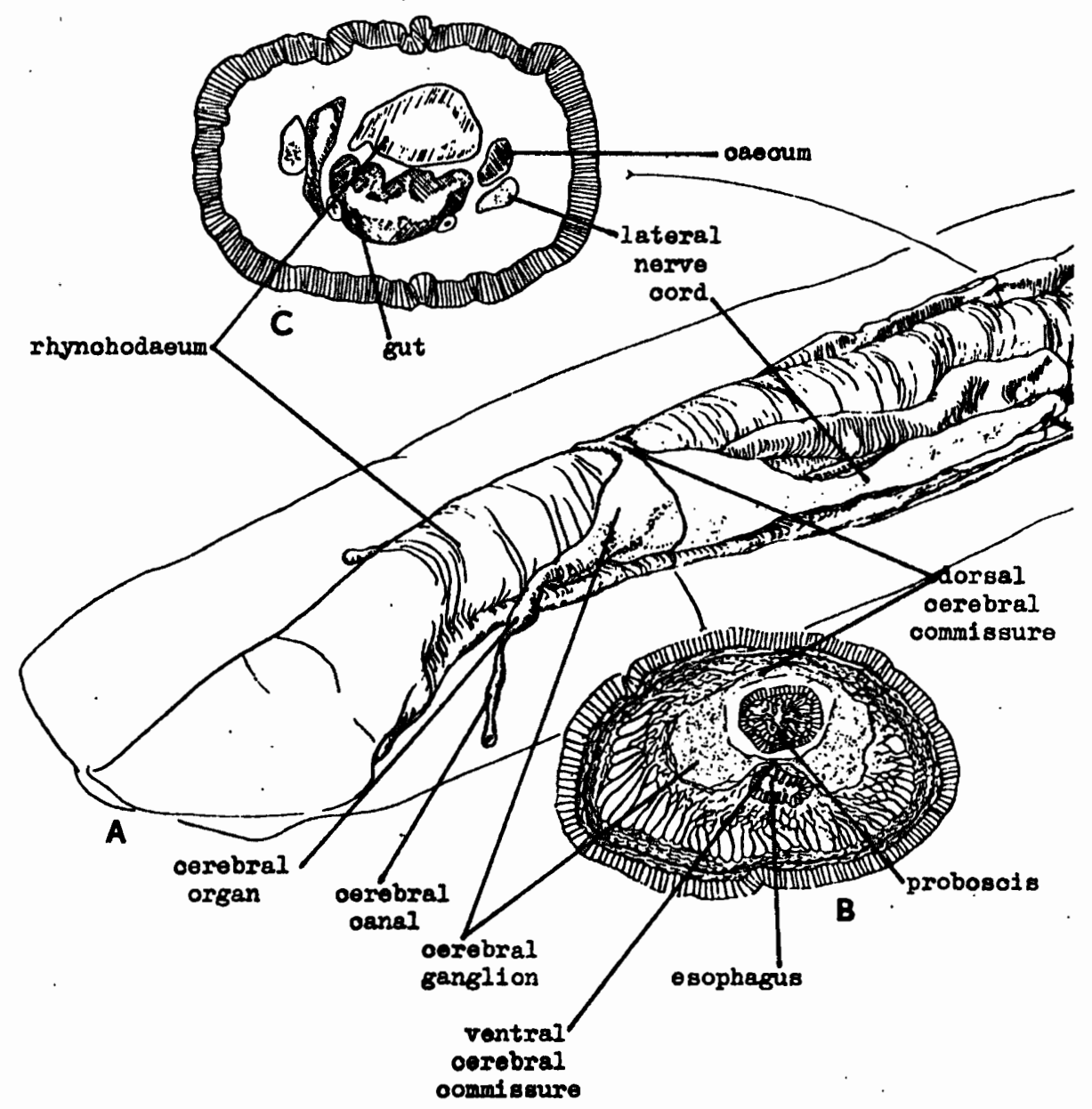

Figure 1. A - Anterior portion of Amphiphorus imparispinosus illustrating major organ systems. B - Cross section through the cerebral ganglia.

$C$ - Cross section posterior to cerebral ganglia. 


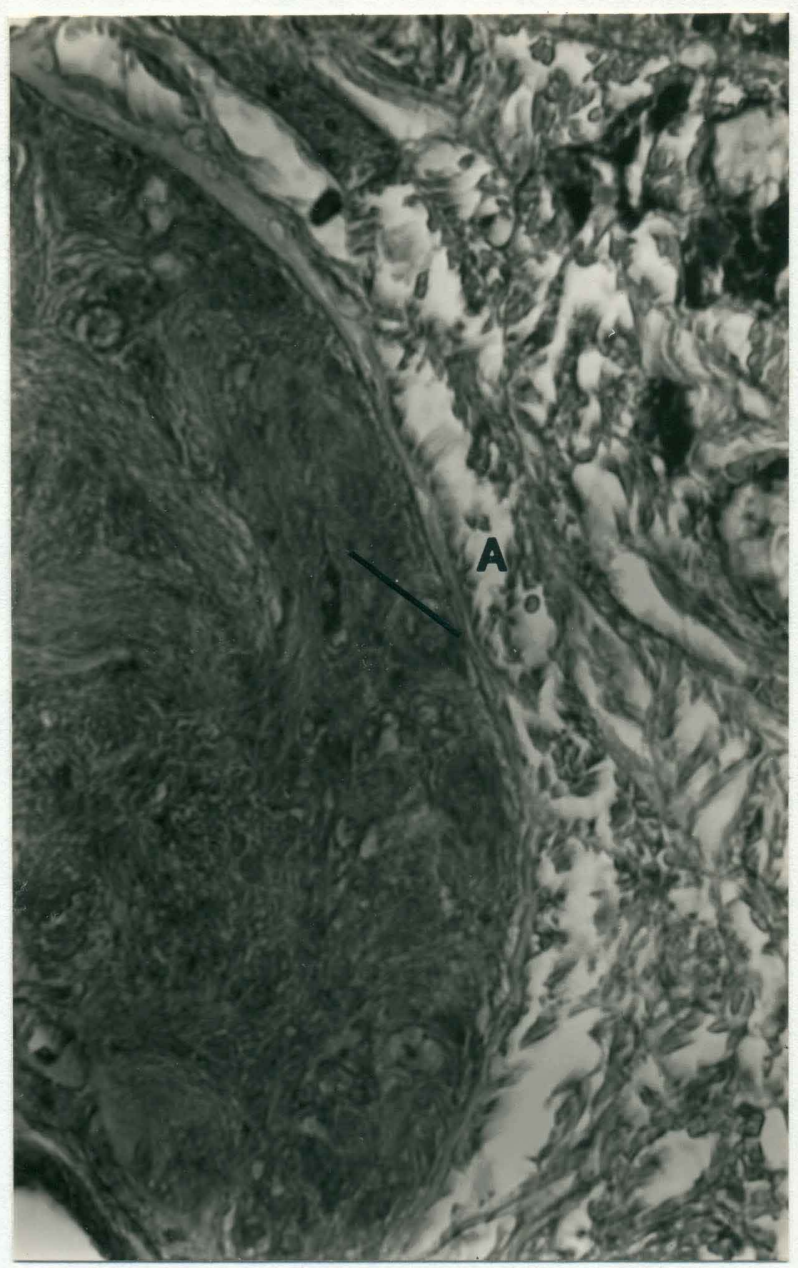

Figure 2. Cross-section of the right dorsal cerebral ganglion of Amphiphorus imparispinosus showing an A ce11 (A). 

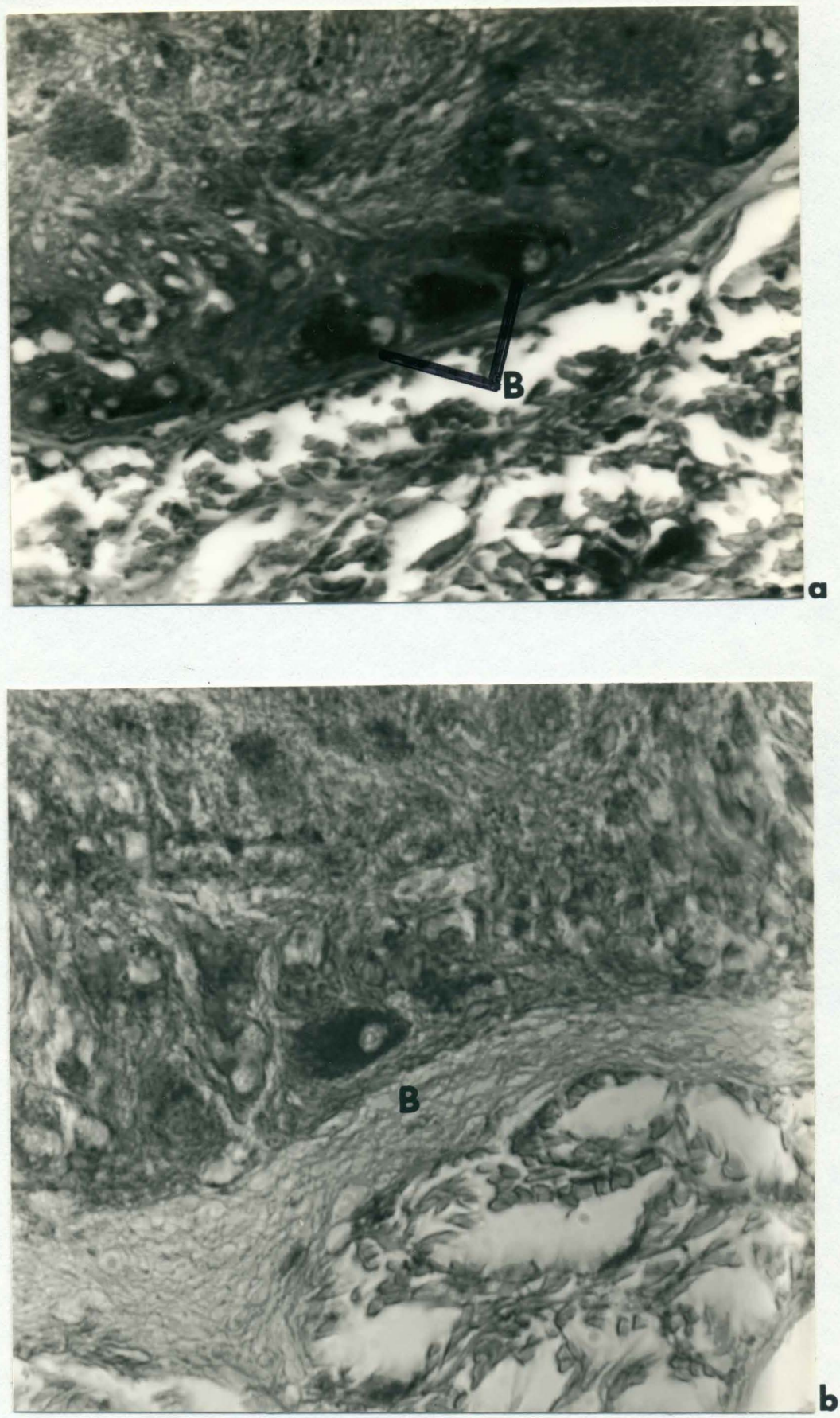

Figure 3. a - Cross section through the left dorsal cerebral ganglion of Amphiphorus imparispinosus showing several B cells (B). b - Cross section through left ventral cerebral ganglia with large B cell. 


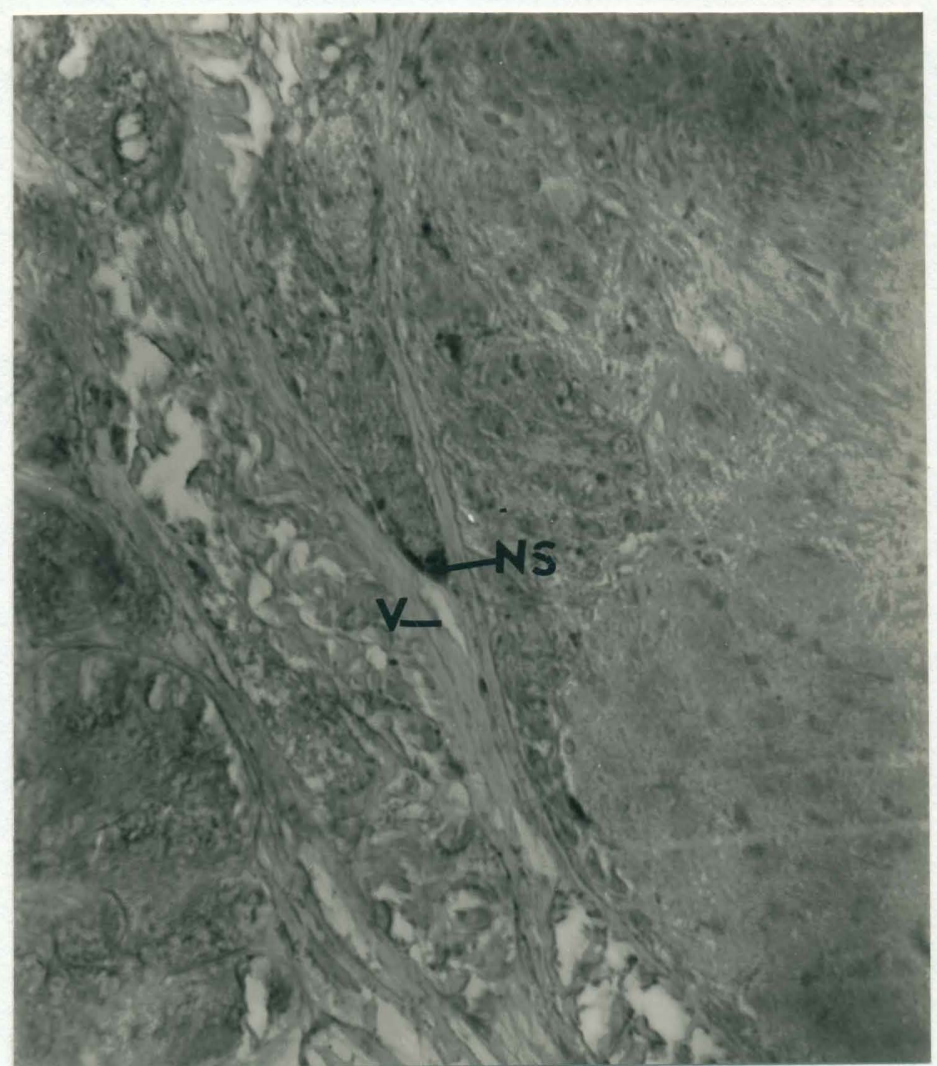

Figure 4. Cross section through right dorsal cerebral ganglion of Amphiphorus imparispinosus showing the accumulation of neurosecretory products (NS) near a blood vessel (V) indicating a possible neurohaemal area. 
II. CYCLICAL NEUROSECRETORY ACTIVITY

The number of neurosecretory cells found within the cerebral ganglia of animals collected over a period of one year suggests an annual cycle of activity. Animals collected from April through August showed a steadily increasing number of neurosecretory cells. The mean number of neurosecretory cells doubled during this five month period. October collections showed a sharp decline in the number of these cells. This low level of secretory activity was maintained through February (Fig. 5; Table I). Separate counts were made on both $A$ and $B$ cells (Fig. 6; Table I). The standard deviations for the occurrence of A cells alone were large and no regular pattern of changes in frequency could be discerned.

\section{THE REPRODUCTIVE CYCLE}

Serial sections of the mid-regions of specimens collected over the year indicated Amphiphorus imparispinosus is dioecious. The gonads are thin-walled sacs that originate from the mesenchyme and are grouped in pairs along the intestine. Spawning season apparently occurs during February and March, males and females maturing at about the same time. Worms collected in the spring (April and May) had very sma11, immature gonads. Gonad size increased slowly throughout summer and fall collections, followed by a rapid increase in the winter. Animals collected in late February 


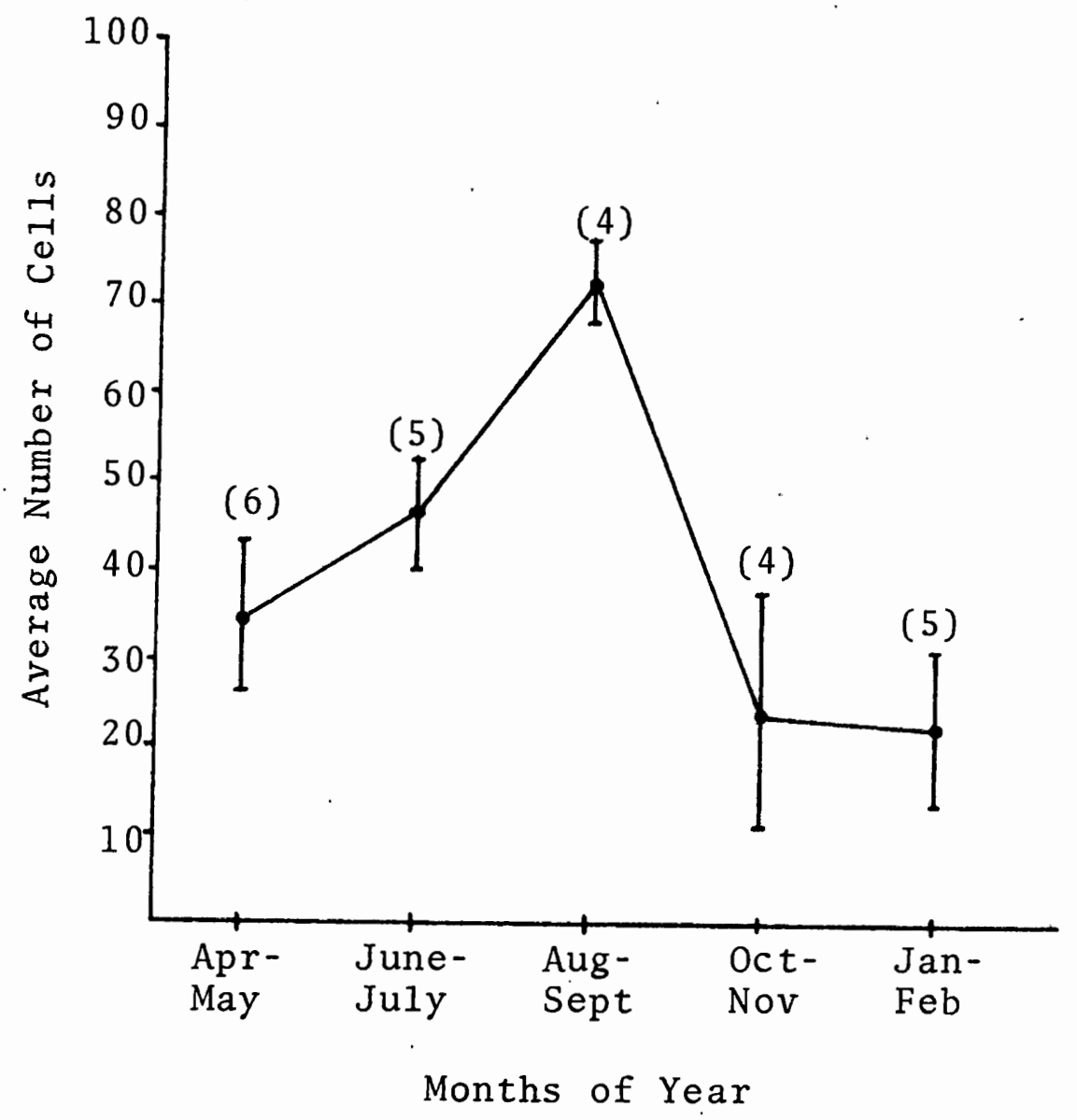

Figure 5. Annual cycle of mean total numbers of neurosecretory cells in the cerebral ganglia of Amphiphorus imparispinosus collected April 1973 to February 1974. Standard deviations are shown for each value of total neurosecretory cell count. Total number of animals included in each sample is given in parentheses. 

AVERAGE NUMBER OF TOTAL NEUROSECRETORY CELLS AND AVERAGE NUMBER OF A AND B CELLS FOUND IN THE
CEREBRAL GANGLIA OF Amphiphorus FROM APRIL 1973 TO FEBRUARY 1974

\begin{tabular}{cccc}
$\begin{array}{c}\text { Total } \\
\begin{array}{c}\text { Neurocretory } \\
\text { Cells }\end{array}\end{array}$ & A Ce11s & B Ce11s & $\begin{array}{c}\text { Number } \\
\text { of } \\
\text { Animals }\end{array}$ \\
\hline 34.8 & 17.6 & 17.2 & 6 \\
46.5 & 15.7 & 30.7 & 5 \\
72.7 & 26.3 & 46.3 & 4 \\
24.3 & 10.0 & 14.3 & 4 \\
22.7 & 10.5 & 12.2 & 5
\end{tabular}

Total neurosecretory cell counts were tabulated on a bimonthly basis in order to increase the sample size of each group and allow for calculation of the standard deviation. No sample could be collected during March. 


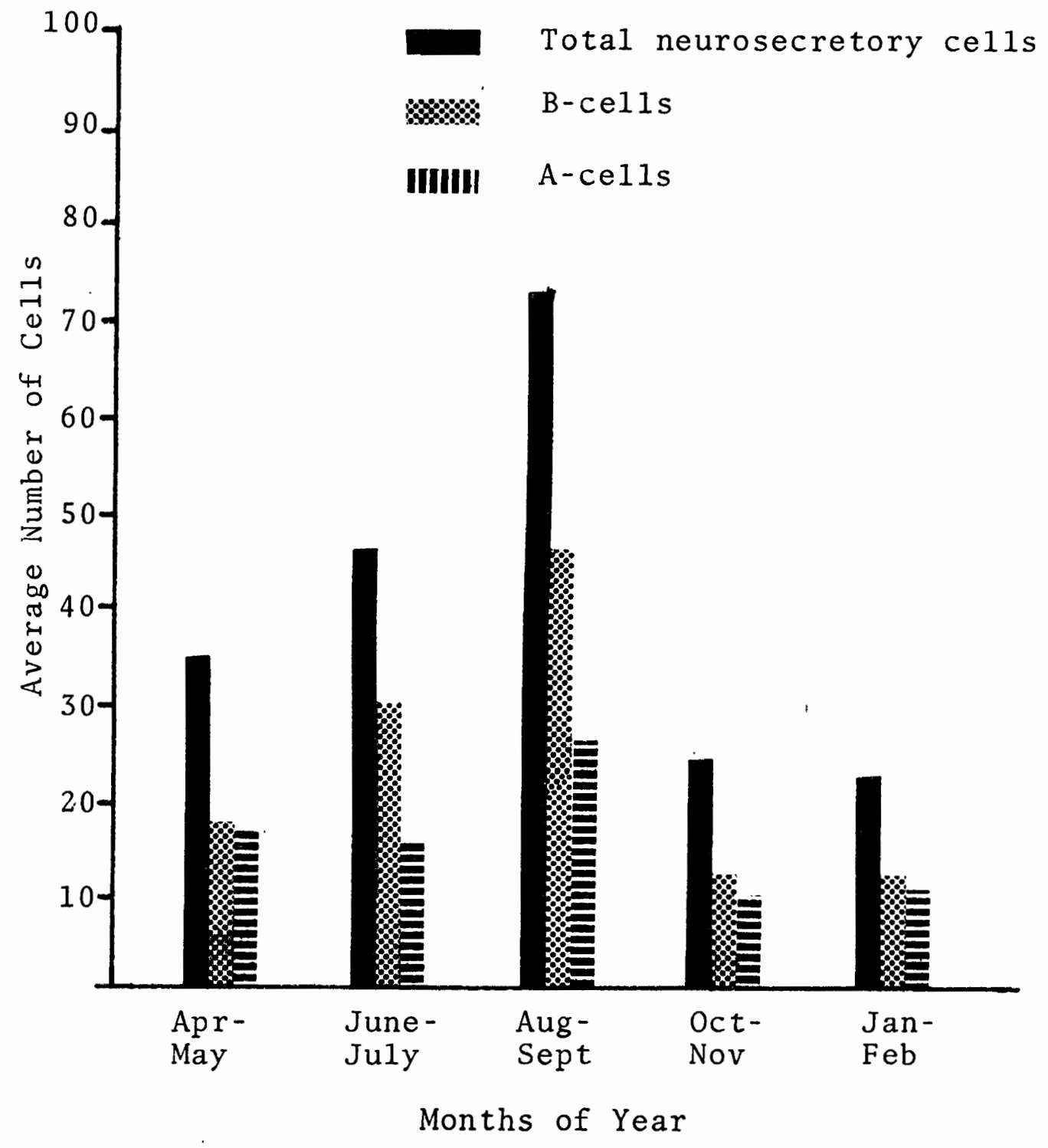

Figure 6. Annual cycle of mean numbers of stainable A-cells and B-cells, and of mean total number of neurosecretory cells in the cerebral ganglia of Amphiphorus imparispinosus collected April 1973 to February 1974. 
were filled with mature gametes, the ovaries or testes being extremely large (Fig. 7). Ovary diameter was chosen as an index of sexual maturity in determing the reproductive cycle since female specimens outnumbered male specimens in most collections and ovary diameter proved to be more easily determined than ova diameter. Each ovary contained several eggs and demarcations between ova were not always visible. The sexual stage of each female was determined by measuring the diameter of several ovaries along the animal's length. These figures were then averaged. Figure 8 illustrates the change in ovary size over the year. 


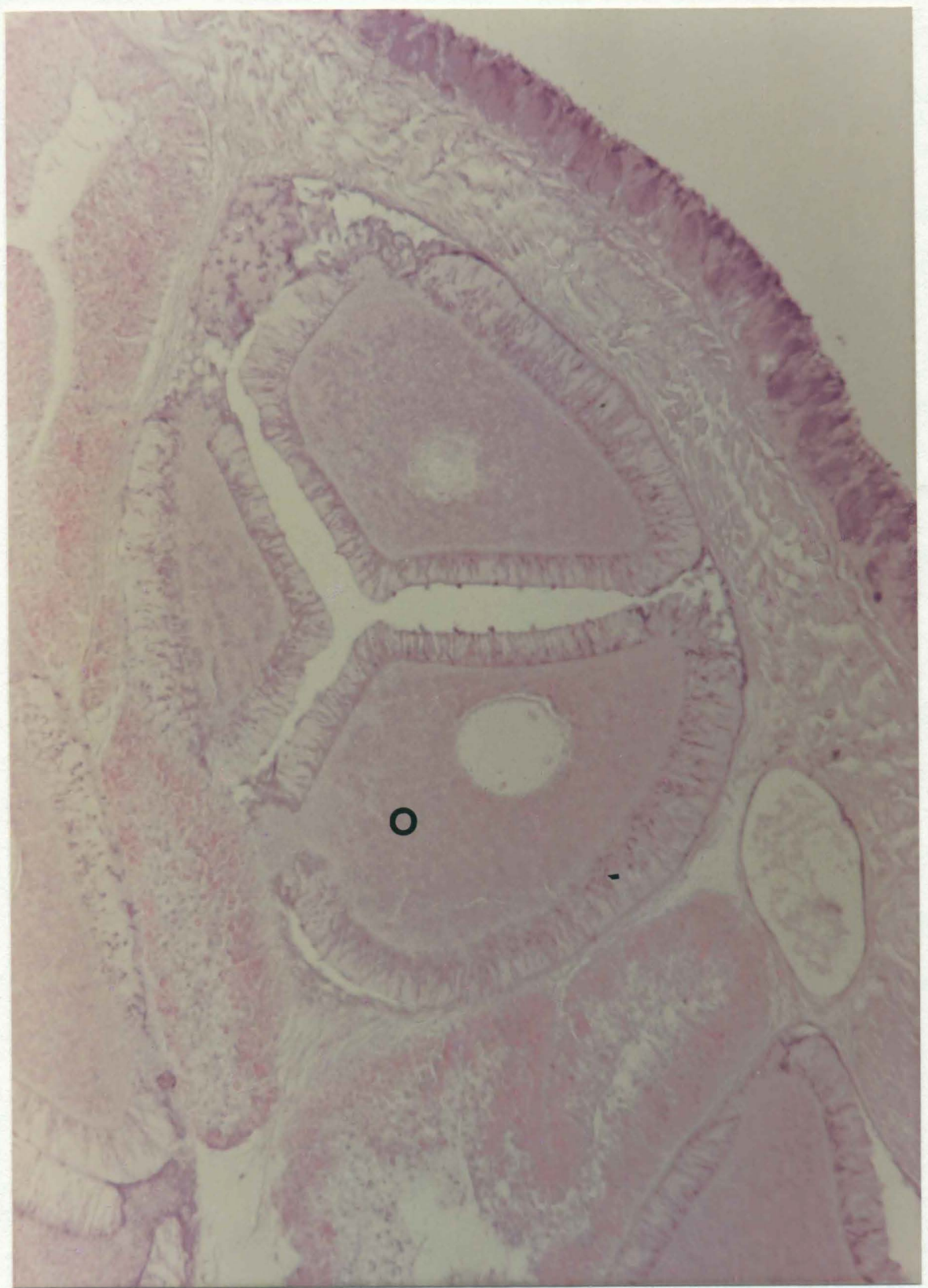

Figure 7. Cross section of a gravid female collected in February showing mature ova (0). X125. 


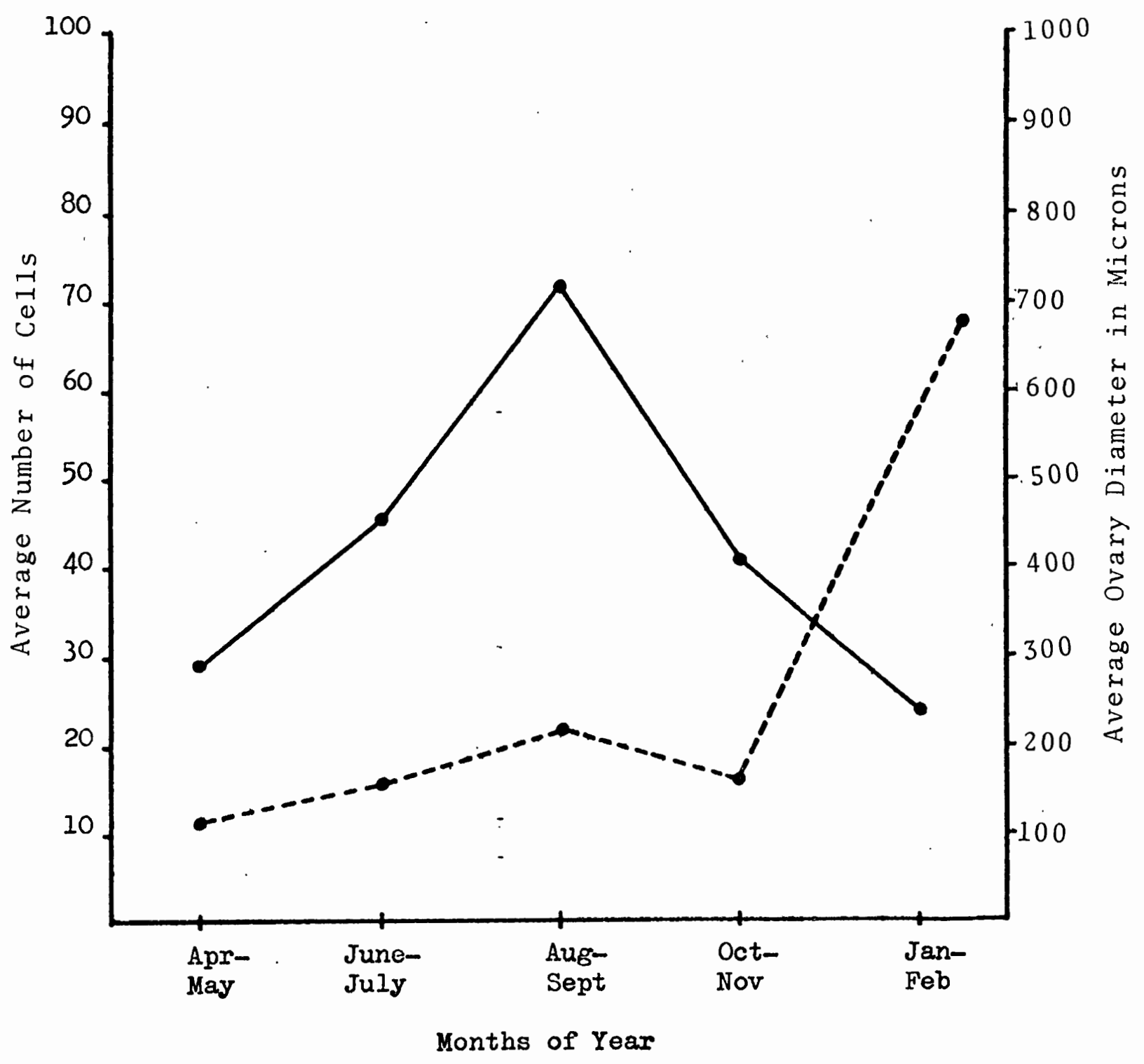

Figure 8. Annual neurosecretory and reproductive cycles in Amphiphorus imparispinosus. Solid line indicates the neurosecretory cycle shown as the mean total neurosecretory cells found within the cerebral ganglia. The reproductive cycle is indicated by the broken line. Points on this line are the mean ovary diameter. Mature ova are found only in the JanuaryFebruary sample. 


\section{DISCUSSION}

Evidence accumulated during this study indicate both sexual maturation and neurosecretory activity within the cerebral ganglia undergo definite seasonal cycles. A causal relationship between the two cycles is a reasonable assumption based on experimental data indicating hormonal control by the cerebral ganglia over gametogenesis in other nemertean species. J. Bierne $(1964,1966,1973)$ reported that extirpation of the cerebral ganglia of Lineus ruber was followed by precocious sexual maturation. Reimplantation of the cerebral ganglia into decerebrate animals prevented early gametogenesis. Bierne proposed that the cerebral ganglia elaborate an inhibiting factor exercising hormonal control over the sexual cycle. Premature lifting of this inhibition by removal of the cerebral ganglia thus causes precocious sexual development.

Figure 8 allows comparison of the sexual and neurosecretory cycles of Amphiphorus. The number of cells stained rises steadily through the spring reaching a peak in August. During this same period mean ovary diameter increases very slowly. The number of neurosecretory cells drops off sharply in the fall reaching its lowest point in February. Mean ovary diameter, however, undergoes a dramatic increase during this same period, mature ova being 
present at the time of lowest secretory activity (i.e., February). One may speculate that the decline in neurosecretion actually represents a release from the inhibitory influence of the cerebral ganglia. There is experimental evidence for an inhibitory hormonal regulation of gametogenesis in work done on other marine worms. Brain removal precipitates the rapid growth of oocytes and premature epitokal metamorphosis in the polychaete, Nereis. Reimplantation of the brain will prevent these phenomena. Normal oocyte growth in this species apparently depends on a progressive decrease in the amount of inhibiting hormones (Clark, 1965; Hausenchild, 1964).

In contrast, if one attempts to explain the reproductive cycle of Amphiphorus by postulating a gonadotropic influence from the cerebral ganglia, the fact that there is a six month lag between the peak in neurosecretion and the ultinate appearance of ripe gametes makes this interpretation unlikely. In the leeches where the brain is known to have a stimulatory effect on gametogenesis, neurosecretory activity is at its highest level only one month before the appearance of mature sperm clusters (Hagadorn, 1966).

It would seem, therefore, that the results of the present study are in accord with previous experiments on the endocrine mechanisms of other nemerteans. That is, that the cerebral ganglia release an inhibitory factor preventing maturation of the gonads (Bierne, 1964, 1966, 1973). 
Definitive proof for the presence of an inhibitory hormone secreted by the brain of Amphiphorus and controlling the annual sexual cycle must await physiological experimentation. This histological study, however, in no way contradicts J. Bierne's proposal for such an inhibitory influence among members of this phylum. 


\section{REFERENCES CITED}

Barnes, R. D. (1974). Invertebrate Zoology, Third Ed. W. B. Saunders, Philadelphia, Penn.

Bayer, F. M. and H. B. Owre (1969). The Free-Living Lower Invertebrates. MacMilian Co., London.

Bern, H. A. (1963). The secretory neuron as a doubly specialized cell. General Physiology of Cell Specialization. Eds. Mazia, D. and A. Tyler. McGraw-Hil1, New York.

Bern, H. A. and I. R. Hagadorn (1965). Neurosecretion. The Structure and Function of the Nervous System of Invertebrates. Eds. Bullock, J. H. and G. A. Horridge. W. H. Freeman, San Francisco.

Bern, H. A. and F. G. W. Knowles (1966). Neurosecretion. Neuroendocrinology, Vol. I. Eds. Martini, L. and W. F. Garong. Academic Press, New York.

Bianchi, S. (1969). On the neurosecretory system of Cerebratulus marginatus (Heteronemertini). Gen. Comp. Endocr. 12: 541-548.

Bierne, J. (1964). Maturation sexuelle anticipée par décapitation de la femelle chez l'Hétéronémerte Lineus ruber Müller. C.r. Acad. Sci. Paris, 259: $4841-4843$.

Bierne, J. (1966). Localisation dans les ganglions cérébroides du centre regulateur de la maturation sexuelle chez la femelle de Lineus ruber Müller (Hétéronémertes). C.r. Acad. Sci. Paris, 262: $1572-1575$.

Bierne, J. (1973). Contrôle neuroendocrinien de la puberté chez la mâle de Lineus rubex Müller (Hétéronémerte). C.r. Acad. Sci.Paris, 276: $363-366$.

Clark, R. B. (1955). The posterior lobes of the brain of Nephtys and mucus-glands of the prostomium. Quart. J. Microscop. Sc., 96: 545-565. 
Clark, R. B. (1965). Endocrinology and the reproductive biology of polychaetes. Ann. Rev. Oceanog. Marine Bio1. 3: 211-255.

Clark, R. B. (1966). Secretory activity in the nervous system. Some Contemporary Studies in Marine Science. Ed. Barnes, H. Allen and Unwin, London.

Clark, R. B. (1969). Endocrine influences in annelids. Gen. Comp. Endocr. Supp1. 2, Proc. Fifth Int'l Symp. Comp. Endocr. Academic Press, New York.

Durchon, M. (1967). L'endocrinologie des Vers et des Molluques. Masson, Paris.

Gabe, M. (1966). Neurosecretion. Pergamon Press, New York.

Gabe, M. (1968). Techniques Histoloques. Masson, Paris.

Gersch, M. (1969). Neurosecretory phenomena in invertebrates. Gen. Comp. Endocr. Supp1. 2, Proc. Fifth Int'1. Symp. Comp. Endocr. Academic Press, New York.

Golding, D. W. (1972). Studies in the comparative neuroendocrinology of polychaete reproduction. Gen. Comp. Endocr. Supp1. 3, Proc. Sixth Int'1 stymp. Comp. Endocr. Academic Press, New York.

Hagadorn, I. R. (1966). Neurosecretion in the Hirudinea and its possible role in reproduction. Amer. Zool. 6: $251-261$.

Hausenchild, C. (1964). Postembryonale entwicklungssteurerung durch ein Gehirn-Hormon bei Platynereis dumerizlii. Zool. Anz. Supp1. 27: 111-120.

Highnam, K. C. and L. Hill (1969). The Comparative Endocrinology of the Invertebrates. American Elsevier, New York.

Hyman, L..H. (1951). The Invertebrates: Platyhe1minthes and Rhynchocoela. The Acoelomate Bilateria. Vol. II. McGraw-Hi11, New York.

Knowles, F. G. W. (1962). Techniques in the study of neurosecretion. Techniques in Endocrine Research. Eds. Eckstein, P. and F. Knowles. Academic Press, New York. 
Lechenault, H. (1962). Sur l'existence de cẹllules neurosécrétrices dans les ganglions cérébroides des Lineidae (Hétéronémertes). C.r. Acad. Sci. Paris, 255: $194-196$.

Lechenault, H. (1963). Sur l'existence des cellules neurosécrétrice chez les Hoplonemértes characteristiques histochemiques de la neurosécrétion chez les némertes. C.r. Acad. Sci. Paris, 256: 32013203 .

Ling, E. A. (1969). The structure and function of the cephalic organ of a nemertine, Lineus ruber. Tissue and Ce11, 1 (3): 503-524.

Ling, E. A. (1970). Further investigations of the structure and function of the cephalic organs of a nemertine, Lineus ruber. Tissue and Cell, 2 (4): $569-588$.

MacGinitie, G. E. and N. MacGinitie (1949). Natural History of Marine Animals. McGraw-Hill, New York.

Scharrer, B. (1955). Hormones in the invertebrates. The Hormones. Vol. III. Eds. Pincus, G. and K. V. Thimann. Academic Press, New York.

Servettaz, F. and M. Gontcharoff (1973). Localisation des cellules neurosécrétrices dans le système nerveux central des Lineus ruber et Lineus lacteus (Hétéronémertes). C.r. Acad. Sci. Paris, 276 (13): 2063-2066.

Servettaz, F. and M. Gontcharoff (1974). Etude cytologique des cellules neurosécrétrices chez Lineus ruber et Lineus lacteus (Hétéronémertes). C.r. Acad. Sci. Paris, 278 (10): 1381-1384.

Wilmoth, J. H. (1967) Biology of Invertebrata. Prentice Ha11, Englewood Cliffs, New Jersey. 